Бурдига Д. М., аспірант

Миколайчук М. М., д.н.держ.упр., професор

Одеський регіональний інститут держсавного управління

Національної академії державного управління при Президентові України м. Одеса, Україна

DOI: https://doi.org/10.30525/978-9934-26-018-6-5

\title{
РОЗВИТОК ВІДНОВЛЮВАЛЬНОЇ ЕНЕРГЕТИКИ ЯК СКЛАДОВОЇ ІННОВАЦІЙНОЇ ЕКОНОМІКИ УКРАЇНИ
}

В умовах подальшої інтеграції України до Європейського Союзу питання розвитку інноваційної економіки на засадах відновлювальних джерел енергії набуває все більшої актуальності.

Дефіцит власних енергетичних ресурсів та залежність від імпорту енергоносіїв $\epsilon$ головною загрозою національної безпеки будь-якої країни. У зв'язку з чим енергетична політика виступає 
базовою умовою існування та розвитку держави. На сьогоднішній день найбільш динамічним, гнучким та послідовним прикладом політики у зазначеній сфері $є$ політика країн $€ \mathrm{C}$, головними завданнями якої $є$ забезпечення надійного постачання енергоносіїв за доступними цінами та зменшення навантаження на навколишнє природне середовище завдяки розвитку відновлювальної енергетики. Досвід країн ЄС у переході від традиційних джерел енергії до відновлюваних свідчить не лише про використання енергоощадних технологій, але й засвідчує, що так звана «зелена енергія» являє собою потужний інструмент у енергозабезпеченні промислово-розвинутих країн, складаючи конкуренцію вугільним, нафтогазовим i атомним електростанціям.

Головною метою «Енергетичної стратегії України до 2035-го року» $\epsilon$ енергоефективність, конкурентоспроможність і безпека [5]. За планами зазначеної стратегії, енерговитратність підприємств і комунально- житлового господарства має зменшитися майже на 20\%, що на 20\% зменшить викиди парникових газів. Відновлювальні джерела енергії мають використовуватися в загальному виробленні електричної та теплової енергії на 20-30\%.

Структура постачання первинної енергії в Україні свідчить (табл. 1), що переважна іiі більшість виробляється в Україні, однак обсягів недостатньо для споживання, що призводить до залежності нашої країни від імпорту. Тому питання щодо розвитку відновлюваних джерел енергії (ВДЕ) в Україні набувають першочергового значення.

Рівень освоєння природного потенціалу відновлювальної енергетики в Україні перебуває на дуже низькому рівні (табл. 2). Частка загального постачання енергії від ВДЕ в 2018 році склала лише 4,4\% у обсязі первинної енергії, збільшившись на 2,4\% порівняно 32013 роком. Найбільшу частку в структурі постачання первинної енергії займає енергія біопалива та відходів, при цьому темпи зростання є найбільшими серед усіх ВДЕ [1]. Найменш розвинутою в енергетиці є вітрова та сонячна 
енергія. Недостатніми є й темпи розвитку гідроенергії, частка якої становить майже один відсоток.

Таблиця 1

Постачання первинної енергії в Україні

\begin{tabular}{|c|c|c|c|c|c|c|}
\hline Показники & 2013 p. & 2014 p. & 2015 p. & 2016 p. & 2017 p. & 2018 p. \\
\hline $\begin{array}{l}\text { Виробництво енергії, } \\
\text { тис. т.н.е. }\end{array}$ & 85247 & 85914 & 76928 & 61614 & 66323 & 58851 \\
\hline $\begin{array}{l}\text { Iмпорт енергії, } \\
\text { тис. т.н.е. }\end{array}$ & 46520 & 39722 & 34437 & 31575 & 29152 & 35261 \\
\hline $\begin{array}{l}\text { Співвідношення } \\
\text { виробництва енергії } \\
\text { з їі імпортом }(1 / 2)\end{array}$ & 1,83 & 2,16 & 2,23 & 1,95 & 2,28 & 1,67 \\
\hline $\begin{array}{l}\text { Експорт енергії, } \\
\text { тис. т.н.е. } \\
\end{array}$ & 8007 & 8213 & 6967 & 1447 & 1427 & 1944 \\
\hline $\begin{array}{l}\text { Співвідношення } \\
\text { імпорту з експортом } \\
\text { енергії }(2 / 3)\end{array}$ & 5,81 & 4,84 & 4,94 & 21,82 & 20,43 & 18,14 \\
\hline $\begin{array}{l}\text { Міжнародні морські } \\
\text { та авіаційні бункери, } \\
\text { тис. т.н.е. }\end{array}$ & 306 & 126 & 131 & 124 & 157 & 251 \\
\hline Зміни запасів, тис. т.н.е. & -966 & -1356 & 1417 & -1529 & 492 & -2291 \\
\hline $\begin{array}{l}\text { Загальне постачання } \\
\text { первинної енергї̈, } \\
\text { тис. т.н.е. }\end{array}$ & 122488 & 115940 & 105683 & 90090 & 94383 & 89625 \\
\hline
\end{tabular}

Як свідчить світова практика, сучасним підходом, який набув популярності в останні роки, є залучення інвестицій через державно-приватне партнерство. Діяльність органів публічної влади та бізнесу у сфері відновлюваної енергетики $\epsilon$ взаємозалежною, оскільки владні структури не володіють достатніми коштами для інвестування у відновлювану енергетику на рівні, який забезпечував би виконання Україною взятих на себе зобов'язань щодо збільшення частки ВДЕ в енергобалансі, 
а бізнес без підтримки влади не може реалізовувати свої проекти [3].

Таблиця 2

Відновлювальні джерела енергії в енергоспоживанні

в Україні

\begin{tabular}{|l|c|c|c|c|c|c|}
\hline \multicolumn{1}{|c|}{ Показники } & $\mathbf{2 0 1 3}$ p. & $\mathbf{2 0 1 4}$ p. & $\mathbf{2 0 1 5}$ p. & $\mathbf{2 0 1 6}$ p. & $\mathbf{2 0 1 7}$ p. & $\mathbf{2 0 1 8}$ р. \\
\hline $\begin{array}{l}\text { Загальне постачання } \\
\text { первинної енергії, } \\
\text { в тому числі: }\end{array}$ & 122488 & 115940 & 105683 & 90090 & 94383 & 89625 \\
\hline $\begin{array}{l}\text { Гідроенергетика, } \\
\text { тис. т.н.е. }\end{array}$ & 901 & 1187 & 729 & 464 & 660 & 769 \\
\hline у \% до підсумку & $0,7 \%$ & $1,0 \%$ & $0,7 \%$ & $0,5 \%$ & $0,7 \%$ & $0,9 \%$ \\
\hline $\begin{array}{l}\text { Енергія біопалива } \\
\text { та відходи, тис. т.н.е. }\end{array}$ & 1522 & 1875 & 1934 & 2102 & 2832 & 3046 \\
\hline у \% до підсумку & $1,2 \%$ & $1,6 \%$ & $1,8 \%$ & $2,3 \%$ & $3,0 \%$ & $3,4 \%$ \\
\hline $\begin{array}{l}\text { Вітрова та сонячна } \\
\text { енергія, тис. т.н.е. }\end{array}$ & 53 & 104 & 134 & 134 & 124 & 14 \\
\hline у \% до підсумку & $0,0 \%$ & $0,1 \%$ & $0,1 \%$ & $0,1 \%$ & $0,1 \%$ & $0,2 \%$ \\
\hline $\begin{array}{l}\text { Загальне постачання } \\
\text { енергії від відновлю- } \\
\text { ваних джерел, тис. т.н.е. }\end{array}$ & 2476 & 3166 & 2797 & 2700 & 3616 & 3964 \\
\hline $\begin{array}{l}\text { Частка постачання } \\
\text { енергії від відновлю- } \\
\text { ваних джерел, \% }\end{array}$ & $2,0 \%$ & $2,7 \%$ & $2,6 \%$ & $3,0 \%$ & $3,8 \%$ & $4,4 \%$ \\
\hline
\end{tabular}

Ще одним дієвим інструментом залучення інвестицій в енергетичний сектор $\epsilon$ «зелені облігації», які являють собою борговий інструмент, кошти від продажу якого спрямовуються виключно на фінансування наявних або ж нових «зелених проектів». Зелені інвестиції набули широкої популярності у світі, за допомогою яких можливо створити додаткові можливості щодо інвестування проектів 3 альтернативної енергетики та можливості залучення світових кліматичних 
фінансів. У 2007 році вперше в світі було випущено зелених облігацій на суму 860 млн. дол., а 2018 року цей показник становив уже 389 млрд. дол. Основними емітентами зелених облігацій в світі є: Європейський банк реконструкції та розвитку, Світовий банк, Європейський інвестиційний банк, Міжнародна фінансова корпорація. Головними їх покупцями виступають європейські інституційні інвестори, для яких фінансування екологічних проектів $є$ демонстрацією їх соціально-відповідальної інвестиційної політики. Роботу над розвитком ринку зелених облігацій в Україні розпочато у 2018 року.

Переваги застосування державно-приватного партнерства та запровадження зелених облігацій у сфері відновлюваної енергетики для сталого розвитку економіки країни [4]:

- сприяють залученню інвестицій;

- сприяють розвитку альтернативних джерел енергії;

- сприяють розробці нової та вдосконаленню вже існуючої нормативно-правової бази, здатної забезпечити розвиток зелених облігацій та державно-приватного партнерства в Україні на взаємовигідних умовах;

- впливають на розвиток інноваційної діяльності;

- сприяють виконанню міжнародних зобов’ язань;

- впливають на розвиток інфраструктури;

- завдяки реалізації зелених проектів покращують імідж країни на міжнародній арені;

- сприяють досягненню сталого розвитку економіки країни.

Основною перешкодою для ефективного розвитку галузі відновлювальної енергетики в Україні є висока вартість проектів та їх низька інвестиційна привабливість 3 огляду на ряд негативних чинників: низький суверенний рейтинг, недосконале законодавче урегулювання енергетичної галузі, недостатня кількість фінансових інструментів інвестування, а також нестабільна політична ситуація [2].

Досвід країн СС у переході від традиційних джерел енергії до відновлюваних свідчить, що альтернативна енергетика являє собою потужний інструмент у енергозабезпеченні промислово- 
розвинутих країн, складаючи конкуренцію вугільним, нафтогазовим i атомним електростанціям. Україна має значний потенціал відновлюваної енергетики, який необхідно використовувати для стимулювання економічної діяльності країни, покращення іiі торгівельного балансу, що надасть змогу не лише оновити основні виробничі фонди в енергетичній сфері, а й створити нові робочі місця, зменшити залежність від імпорту енергоносіїв та досягти сталого розвитку економіки та іiі інноваційного сектору.

Одним із підходів, який надає можливість застосування дієвих механізмів залучення інвестицій, що набув популярності у світовій практиці, $€$ державно-приватне партнерство та введення в обіг «зелених облігацій». Це дозволить реалізувати Національну стратегію розвитку України в енергетичній сфері, а також сприятиме сталому розвитку інноваційно-енергоефективної економіки України.

\section{Література:}

1. Башинська Ю.І., Жук П.В. Перспективні шляхи розвитку публічноприватного партнерства у сфері відновлюваної енергетики регіону. Регіональна економіка. 2016. № 3. С. 63-68.

2. ДПП в енергетиці: чого чекаємо в законодавчій сфері. URL: http://yur-gazeta.com/publications/practice/energetichne-pravo/dpp-v-energetici-chogochekaemo-v-zakonodavchiy-sferi.html (дата звернення: 01.12.2020).

3. Закон України про державно-приватне партнерство. URL: https://zakon.rada.gov.ua/laws/show/2404-17 (дата звернення: 01.12.2020).

4. Павлюк К. В., Павлюк С. М. Сутність і роль державно-приватного партнерства в соціально- економічному розвитку держави. Наукові праиі Кіровоградського начіонального технічного університету. Економічні науки. 2010. № 17. C. 10-19.

5. Про схвалення Енергетичної стратегії України на період до 2035 року «Безпека, енергоефективність, конкурентоспроможність». URL: https://zakon.rada.gov.ua/laws/show/605-2017-p. (дата звернення: 01.12.2020). 